African Journal of Sustainable Agricultural Development | ISSN: 2714-4402

Vol. 1, Number 3 (July-September, 2020) | www.ijaar.org/ajsad

\title{
GROWTH ATTRIBUTES OF SOME SOYABEAN (GLYCINE MAX.L. MERIL) VARIETIES IN DELTA SOUTH AGRO-ECOLOGICAL ZONE OF DELTA STATE
}

\author{
UYO, Mary \\ Department of Agricultural Technology, \\ School of Agriculture, \\ Delta State Polytechnic, Ozoro. \\ Corresponding Author: uyo.mary2603@gmail.com
}

\begin{abstract}
This study was carried out in the Teaching and Research Farm of the Department of Agricultural Technology of Delta State Polytechnic, Ozoro in 2019 to evaluate the growth attributes of selected soyabean varieties using Randomized Complete Block Design replicated three times. Three varieties released at the 2015 Soyabean International Trials; TGX 1904 6F, TGX $1910-11 F$, TGX 1910 - 15F and TGX 1910 - 8F (control) were used. Growth variables such as plant height, number of leaves and leaf area were obtained at 4, 8, 12 and 16 weeks after planting. Data obtained were subjected to analysis of variance and treatments were separated using least significant difference Test. The results obtained indicated that TGX $19046 F$ was superior to all the other varieties in terms of germination count and all the growth variables assessed at the designated stages of growth. It is therefore recommended that arising from the superior growth attributes of TGX 1904 6F, it should be adopted by farmers in Delta South Agro-ecological Zone of Delta State that are desirous of growth characteristics as the focus of cultivating soyabean.
\end{abstract}

Keywords: Soyabean, Varieties, Growth, Delta, Agro-ecological. 


\section{INTRODUCTION}

Soyabean (Glycine max, L. Merrill) belongs to the Family Fabaceae (Wikipedia, 2011). It is a versatile species of the grain food legume (Gibson and Benson, 2011). It is regarded as a miracle bean due to its economic and dietary importance (Barwa, 1990). It constitutes a rich source of valuable and high quality edible vegetable oil (20\%), superior, protein (40\%), carbohydrates/soluble sugars $(35 \%)$ and $5 \%$ ash making it serve as a source of food to humans and as feed to animals (Singh et al.,1987; Thompson, 1981). The crop is a benchmark Nitrogen fixing Legume capable of fixing up to $180 \mathrm{kgN} / \mathrm{ha}$ symbiotically; $80 \%$ of which is harvested as beans (Williams et al., 1980) and is second only to Sebania rostrate which can fix more than $250 \mathrm{kgN} / \mathrm{ha}$ in 50 days in both roots and stems (Ludwig, 1989; Ronuaclo et al., 1983).

Successful cultivation of soyabean was first achieved in Samatu, Zaria in 1923 (Nyiakura, 1982) and later in 1937 when the most adaptable variety; Malayan was introduced (Wudiri, 1988, 11TA, 1990). The crop is one of the mandate crops of the International Institute of Tropical Agriculture with several efforts geared towards enhancing consistent improvements in average yield levels and reduction in production costs through regular observation trials using varying agronomic practices. The crop is expected to be relevant in many cropping systems of the tropics and sub-tropics where the farms are mainly subsistence with very little or no mechanization (FAO, 2001). However, several constraints that may deter the attainment of the production of soyabean to attain its potential role include use of high yielding varieties from temperate ecologies that may flower too early under short day length, use of varieties capable of ineffective modulation with indigenous rhizobial populations, poor seed longerity, pest and disease attack as well as inappropriate agronomic practices amongst others. Production of the crop has been concentrated in the areas of the Sudan and Guinea Savannah zones in Nigeria (11TA, 1992a). There is no substantial evidence of production of the crop in the Tropical Rainforest Zone of Nigeria which is expected to have varying climatic, environmental and soil conditions. On this basis therefore, it is pertinent considering the enormous relevance of soyabean to mankind to key into sustained efforts requiring integrated approaches to maintain and evaluate improved varieties of soyabean in different ecological zones (Delta South Agro-ecological Zone in particular) with a view to ascertaining its attributes for appropriate information to farmers in the course of its release for cultivation. In the light of the foregoing, this study is aimed at ascertaining selected growth and yield attributes of selected soyabean varieties in Delta South Agro-ecological Zone of Delta State.

\section{MATERIALS AND METHODS}

The study was carried out in the Teaching and Research Farm of the Department of Agricultural Technology, School of Agriculture, Delta State Polytechnic, Ozoro (Latitude $6^{0}$ $15^{\prime} \mathrm{N}$, Longitude $07^{0} 10^{\prime} \mathrm{E}$ ) in Isoko North Local Government Area within the Delta South Agro-ecological Zone of Delta State. The Rainfall pattern of the area is bimodial (Long period - March to July and Short period - September to November), with July experiencing the highest amount of rainfall with a break in August. The minimum temperature experienced is $21.50^{\circ} \mathrm{c}$ and maximum temperature is $32.20^{\circ} \mathrm{c}$. The soil is alkaline and classified as ultisol with drained coastal plain sand of Benin formation. The prominent weeds in the area are swine weed and calapogonium spp. The previous cropping pattern was sole cropping with 
cassava being the main crop. The experiment was established during the cropping season of May to September, 2019.

\section{PRE-PLANTING SOIL ANALYSIS}

Soil samples were randomly collected from the soil surface $(0-13 \mathrm{~cm})$ before commencement of the experiment with Auger. The sample was bulked and air-dried for four days and passed through a $2 \mathrm{~mm}$ sieve. Analysis was carried out to determine the Physiochemical properties in the soil science laboratory of the Delta State University, Asaba Campus (Fig I).

\section{PLANTING MATERIAL}

The cultivars used was TGX 1904 - 6F, TGX 1910 - 11F, TGX 1910 - 15F and TGX $1908-$ $8 \mathrm{~F}$. They were selected from over 20 varieties of soyabean released by the International Institute of Tropical Agriculture in the 2015 soyabean International Observation Trials.

\section{FIELD EVALUATION}

The experimental field measured $13.50 \mathrm{~m} \times 14.00 \mathrm{~m}$, the area was clean cleared, debris packed and burnt. The site was ploughed and subsequently harrowed. Poultry manure was placed on the site two weeks before planting by broadcast and subsequent pulverization in to the soil. The site was divided into three blocks and four plots per block leaving the trial site with twelve plots. Each plot measured with $1 \mathrm{~m}$ between blocks and $0.5 \mathrm{~m}$ between plots.

\section{CULTURAL PRACTICES}

The soyabean seed were planted on the $15^{\text {th }}$ of May, 2019. This was after the seeds soaked for a twenty (20) minutes period to increase the moisture content to reawaken the embryo for ease of germination. Planting was done at a spacing of $10 \mathrm{~cm} X 75 \mathrm{~cm}$ within the plots and at a depth of $2 \mathrm{~cm}$. Two seeds were planted per hole. Manual weeding was carried out three weeks after planting and subsequently at every four weeks interval. The seedlings were protected from pod sucking insects at eight weeks after planting by spraying Nuvacron at a rate of 2L/ha (Olowe and Alofe, 1992).

\section{DATA COLLECTION AND PROCEDURE}

Three plants were randomly selected from each plot from the net rows and tagged for sampling at various stages of growth and yield. The growth parameters were collected at 4, 8, 12 and 16 weeks after planting. The growth parameters were germination count, plant height, number of leaves, plant height and leaf area. The yield parameters were collected at 8,12 and 16 weeks after planting. The yield parameter collected were number of days to 50\% flowering, number of flowers and number of pods per plant. The data collected were subjected to analysis of variance and the treatment means separated using LSD. 


\section{RESULTS AND DISCUSSION}

The germination count of the soyabean varieties were assessed over a five to eight days period.

Table 1

\begin{tabular}{|c|c|c|c|c|}
\hline \multirow[b]{2}{*}{ Date } & \multicolumn{4}{|c|}{ Varieties/Average Germination Count } \\
\hline & TGX 1904-6F & TGX 1910 - 11F & TGX 1910 - 15F & TGX 1908-8F \\
\hline 20-05-2019 & 80 & 78 & 69 & 72 \\
\hline 21-05-2019 & 125 & 123 & 90 & 120 \\
\hline 22-05-2019 & 156 & 159 & 133 & 131 \\
\hline 23-05-2019 & 180 & 174 & 169 & 169 \\
\hline Average & 132.25 & 133.50 & 115.25 & 121.50 \\
\hline
\end{tabular}

Source: Field Data, 2019.

The data available indicated that TGX 1904 - 6F recorded the highest number of germinated seeds on the first day of assessment and also on the last day of assessment. The variety also recorded the highest number of average germination. TGX $1910-15 \mathrm{~F}$ recorded the least number of germinated seeds on the first day of assessment and also the overall least average germination. The differences in germination count may have arisen from several underlying internal and external factors. The internal factors may be associated with the genetic makeup and the external factors may be the soil and climatic factors. This finding is in consonance with the report by the Raw Material and Development Council (2004) that the performance of a crop is associated with the planting material genetic potential. 
Table 2: Comprehensive Summary of Selected Growth Attributes of Soyabean Varieties

\begin{tabular}{|c|c|c|c|c|c|}
\hline \multirow{17}{*}{$\begin{array}{l}\text { Growth } \\
\text { Attribute }\end{array}$} & Weeks after planting & Variety & Treatment Mean & Mean Difference & LSD Value \\
\hline & \multirow[t]{4}{*}{4} & TGX 1904 - 6F & $10.20 \mathrm{a}$ & 1.30 & \multirow[t]{4}{*}{2.96} \\
\hline & & TGX $1910-11 \mathrm{~F}$ & $8.51 \mathrm{a}$ & -0.39 & \\
\hline & & TGX $1910-15 \mathrm{~F}$ & $9.30 \mathrm{a}$ & 0.40 & \\
\hline & & TGX 1908 - 8F & 8.90 & - & \\
\hline & \multirow[t]{4}{*}{8} & TGX $1904-6 \mathrm{~F}$ & $20.40 \mathrm{~b}$ & 2.40 & \multirow[t]{4}{*}{1.60} \\
\hline & & TGX $1910-11 \mathrm{~F}$ & $16.80 \mathrm{a}$ & -1.20 & \\
\hline & & TGX $1910-15 \mathrm{~F}$ & $19.00 \mathrm{a}$ & -1.00 & \\
\hline & & TGX 1908 - 8F & 18.00 & - & \\
\hline & \multirow[t]{4}{*}{12} & TGX $1904-6 \mathrm{~F}$ & $31.60 \mathrm{~b}$ & 5.60 & \multirow[t]{4}{*}{1.81} \\
\hline & & TGX $1910-11 \mathrm{~F}$ & $28.20 \mathrm{~b}$ & 2.20 & \\
\hline & & TGX $1910-15 \mathrm{~F}$ & $27.00 \mathrm{a}$ & 1.00 & \\
\hline & & TGX $1908-8 \mathrm{~F}$ & 26.00 & - & \\
\hline & \multirow[t]{4}{*}{16} & TGX $1904-6 \mathrm{~F}$ & $48.00 \mathrm{~b}$ & 9.00 & \multirow[t]{4}{*}{6.34} \\
\hline & & TGX $1910-11 \mathrm{~F}$ & $43.00 \mathrm{a}$ & 4.00 & \\
\hline & & TGX $1910-15 \mathrm{~F}$ & $44.00 \mathrm{a}$ & 5.00 & \\
\hline & & TGX $1908-8 \mathrm{~F}$ & 39.00 & - & \\
\hline \multirow{16}{*}{$\begin{array}{l}\text { Number } \\
\text { of leaves }\end{array}$} & \multirow[t]{4}{*}{4} & TGX $1904-6 F$ & $28.00 \mathrm{~b}$ & 11.00 & \multirow[t]{4}{*}{7.89} \\
\hline & & TGX $1910-11 \mathrm{~F}$ & $18.00 \mathrm{~b}$ & 1.00 & \\
\hline & & TGX $1910-15 \mathrm{~F}$ & $14.00 \mathrm{~b}$ & -3.00 & \\
\hline & & TGX $1908-8 \mathrm{~F}$ & 17.00 & - & \\
\hline & \multirow[t]{4}{*}{8} & TGX $1904-6 \mathrm{~F}$ & $39.00 \mathrm{~b}$ & 11.00 & \multirow[t]{4}{*}{15.12} \\
\hline & & TGX $1910-11 \mathrm{~F}$ & $30.00 \mathrm{~b}$ & 2.00 & \\
\hline & & TGX $1910-15 \mathrm{~F}$ & $25.00 \mathrm{~b}$ & -3.00 & \\
\hline & & TGX 1908 - 8F & 28.00 & - & \\
\hline & \multirow[t]{4}{*}{12} & TGX $1904-6 \mathrm{~F}$ & $50.00 \mathrm{a}$ & 8.00 & \multirow[t]{4}{*}{4.69} \\
\hline & & TGX $1910-11 \mathrm{~F}$ & $49.00 \mathrm{~b}$ & 2.00 & \\
\hline & & TGX $1910-15 \mathrm{~F}$ & $39.00 \mathrm{a}$ & -3.00 & \\
\hline & & TGX $1908-8 \mathrm{~F}$ & 42.00 & - & \\
\hline & \multirow[t]{4}{*}{16} & TGX $1904-6 \mathrm{~F}$ & $66.00 \mathrm{~b}$ & 12.00 & \multirow[t]{4}{*}{8.56} \\
\hline & & TGX $1910-11 \mathrm{~F}$ & $57.00 \mathrm{a}$ & 2.00 & \\
\hline & & TGX $1910-15 \mathrm{~F}$ & $53.00 \mathrm{a}$ & -1.00 & \\
\hline & & TGX $1908-8 \mathrm{~F}$ & 54.00 & - & \\
\hline \multirow[t]{16}{*}{ Loaf area } & \multirow[t]{4}{*}{4} & TGX $1904-6 \mathrm{~F}$ & $9.50 \mathrm{a}$ & 2.26 & \multirow[t]{4}{*}{4.69} \\
\hline & & TGX $1910-11 \mathrm{~F}$ & $8.32 \mathrm{a}$ & 2.08 & \\
\hline & & TGX $1910-15 \mathrm{~F}$ & $6.20 \mathrm{a}$ & -1.04 & \\
\hline & & TGX $1908-8 \mathrm{~F}$ & 7.24 & - & \\
\hline & \multirow[t]{4}{*}{8} & TGX $1904-6 \mathrm{~F}$ & $12.39 \mathrm{a}$ & 2.35 & 2.80 \\
\hline & & TGX $1910-11 \mathrm{~F}$ & $10.40 \mathrm{a}$ & -0.26 & \\
\hline & & TGX $1910-15 \mathrm{~F}$ & $6.20 \mathrm{a}$ & 2.15 & \\
\hline & & TGX $1908-8 \mathrm{~F}$ & 10.14 & - & \\
\hline & 12 & TGX $1904-6 \mathrm{~F}$ & $16.50 \mathrm{~b}$ & 2.35 & 1.03 \\
\hline & & TGX $1910-11 \mathrm{~F}$ & $13.49 b$ & -0.65 & \\
\hline & & TGX $1910-15 \mathrm{~F}$ & $16.30 \mathrm{a}$ & 2.15 & \\
\hline & & TGX $1908-8 \mathrm{~F}$ & 14.15 & - & \\
\hline & 16 & TGX $1904-6 \mathrm{~F}$ & $24.20 \mathrm{~b}$ & 5.82 & 3.90 \\
\hline & & TGX $1910-11 \mathrm{~F}$ & $18.48 \mathrm{a}$ & 0.10 & \\
\hline & & TGX $1910-15 \mathrm{~F}$ & $19.32 \mathrm{a}$ & -0.16 & \\
\hline & & TGX 1908 - 8F & 18.38 & - & \\
\hline
\end{tabular}

Means with similar alphabets are most significantly different at $P<0.05$ using LSD. 
The selected growth attributes of the soyabean varieties shown in Table 2 indicates that at four weeks after planting (4WAP) all the soyabean varieties were not significantly different with regards to plant height. But at 8WAP, only TGX $1904-6 \mathrm{~F}(20.40)$ was significantly different from the other treatments. As 12WAP, TGX 1904 - 6F (31.60) and TGX $1910-$ $11 \mathrm{~F}$ (28.20) were significantly different while TGX $1910-15 \mathrm{~F}$ (27.00) was not significantly different. At 16WAP, TGX 1904 -15F (44.00) were not significantly different.

At 4wap and 8wap, the data showed that there were significant differences between the soyabean varieties with regards to the number of leaves. At 12 WAP, TGX 1904-6F (50.00) and TGX 1910 - 15F (39.00) were not indicating significant difference while TGX $1910-$ $11 \mathrm{~F}(49.00)$ was significantly different. At 16WAP, TGX $1904-6 \mathrm{~F}$ (66.00) was significantly different while TGX 1910 -11F (57.00) and TGX 1910 - 15F (53.00 were not significantly different. Data on leaf area shows that at $4 \mathrm{WAP}$ and $8 \mathrm{WAP}$, all the soyabean varieties were significantly different. But at 12WAP, TGX 1904 - 6F (16.50) and TGX $1910-15 \mathrm{~F}$ (16.30) were not significantly different while TGX 1910 - 11F (13.49) was significantly different. At 16WAP, TGX 1904 - 6F (24.20) was significantly different while TGX 1910 - 11F (19.48) and TGX 1910 - 15F (19.32) were not significantly different.

From the foregoing, the evaluated soyabean varieties can be noted to be somewhat similar and markedly different with respect to plant height, number of leaves and leaf area at different stages of growth. The observations may be attributed to a combination of several factors arising from the variations in genetic potential and micro-environmental conditions to which the varieties of soyabean are exposed to. This is in consonance with the assertion of Bounde (1998) who reported that variations in growth and yield of soyabean may be due to climatic factors. This is further supported by the findings of Ugur et al. (2005) that morphological characters are resultant effect of the genetic constitution of cultivars.

The differences in plant height, number of leaves and leaf area may be attributed to a combination of several factors arising from the genetic potential of the crop and variation in micro - environmental condition. 


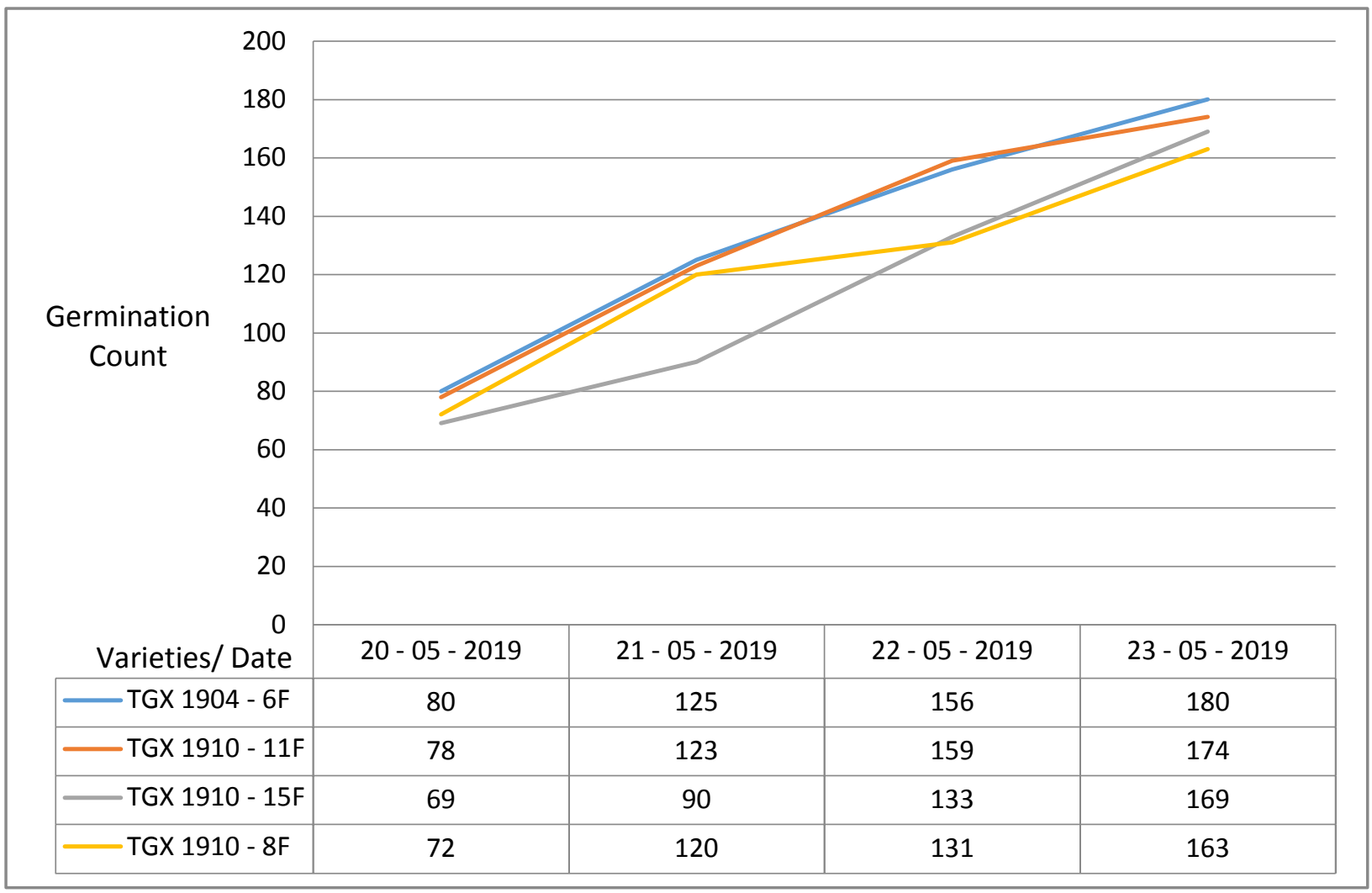

\section{CONCLUSION AND RECOMMENDATION}

This study was carried out to evaluate some growth attributes of selected soyabean varieties in Delta South Agro-ecological Zone of Delta State. The variables were measured to achieve the objectives of the study - Plant Height, Number of Leaves and Leaf Area. Based on the results of the study, the following major findings and conclusions were made;

1. TGX $1904-6 \mathrm{~F}$ recorded the overall highest average germination count (135.25) followed by TGX 1910 - 11F (133.50), TGX 1910 - 8F (121.50) and TGX $1910-$ 15F (115.25) being the least. Two of the three varieties TGX $1904-6 \mathrm{~F}$ and TGF $1910-11 \mathrm{~F}$ super-ceded the control variety $1910-8 \mathrm{~F}$ while TGX $1910-15 \mathrm{~F}$ fell short of it.

2. TGX $1904-6 \mathrm{~F}$ proved to be superior to other soyabean varieties at all stages of growth for all the growth variables assessed.

In view of the results and findings of the study, it is recommended that in cultivating soyabean in Delta South Agro-ecological Zone with a superior growth characteristics as a focus, TGX $1904-6 \mathrm{~F}$ is recommended for adoption. 


\section{ACKNOWLEDGEMENT}

I wish to acknowledge the support rendered by the Department of Agricultural Technology, Delta State Polytechnic, Ozoro, Nigeria in providing available space for the conduct of the research. The support from other colleagues in the Department such as B. J. O. Akpobasa and Mr. P. E. Kator amongst others is also commendable.

\section{REFERENCES}

Banwa, I. 1990 Soyabean Varietal Trials in Yola, Adamawa State. An unpublished BSc. Dissertation of the Federal University of Technology Yola, Adamawa State.

International Institute of Trophical Agriculture 1992a. Soyabean Recipes. Integrated Farming System Programme IAR \& TAOU. Moore Plantation, Ibadan, Nigeria.

Nyiakura .O. 1982 Soyabean Production in Nigeria; Prospects and Problems. In proceeding of the $2^{\text {nd }}$ National Meeting of the Nigerian Soyabean Scientist Publication No 11.

Ugur, B, Mehmet, S, Abdurahim, T.G, Zerk, M.T and Esvet, A 2005. Forage and Grain Performance of Soyabean lines. Journal of Central Eurpean Agriculture 63;397 - 402

Wudiri,B 1998 Chairman's Address to participents of the Nigerian Soyabean Association's Conference. In proceedings of the $8^{\text {th }}$ National Soyabean Conference. 